\title{
Science-based outreach helps stem sudden oak death
}

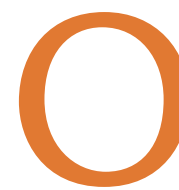

ne of the biggest challenges in controlling sudden oak death is that prevention is the best treatment, but most efforts begin only after trees are already infected. "People don't deal with this disease except in crisis mode," says Janice Alexander, outreach coordinator for the California Oak Mortality Task Force. "We're trying to reach people on the leading edge of the pathogen before it's a crisis."

Caused by the water mold Phytophthora ramorum, sudden oak death was first found in California in Marin County during 1995. This pathogen thrives in cool, moist climates; spreads during rainy springs via air, water and soil; and is carried by more than 100 native and horticultural plant species. In California wildlands, P. ramorum kills tanoak trees and four types of oaks: black, canyon live, coast live and Shreve's. By 2006, about a million trees had died and another million were infected in California. Today the disease has spread to 14 coastal counties from Monterey to Humboldt, as well as southern Oregon.

The California Oak Mortality Task Force (COMTF) was formed in 2000 to unify efforts to control sudden oak death, ranging from research to management to education. Statewide about $\$ 250,000$ per year is spent on prevention and outreach, which is funded by the U.S. Forest Service. COMTF members include government agencies, nonprofit organizations and university researchers, and outreach is coordinated by UC.

In 2007, prevention and treatment outreach included training sessions for coastal wildlands and nurseries, and community meetings in afflicted

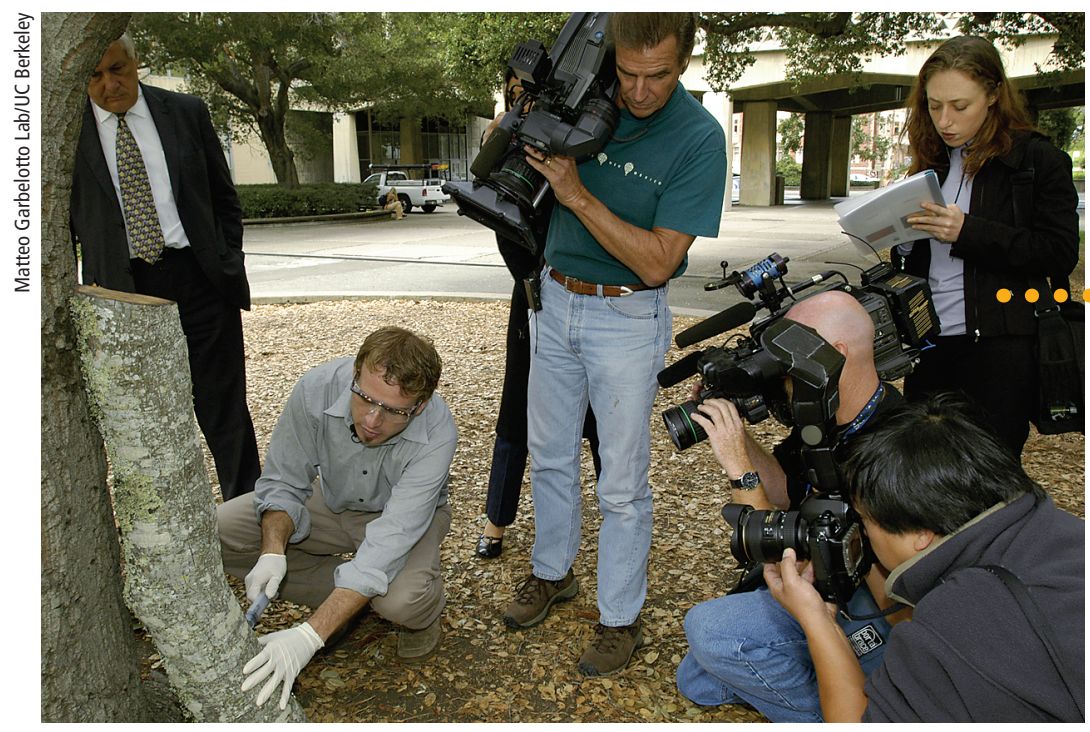

counties. COMTF also maintains a comprehensive sudden oak death Web site, and produces a monthly newsletter that includes updates on new host plants, regulatory changes and the latest research.

Oaks in infected groves can sometimes escape the disease, which spreads in weather-driven cycles. Infections peak during rainy years, and expanding outreach is key to preparing for the next wave of sudden oak death. "The disease is in a lull right now because the winters haven't been very wet," says Chris Lee, COMTF northern outreach coordinator. "We want to be ready when it starts to spread again."

\section{Science-based guidelines}

COMTF uses peer-reviewed science to help clear up misconceptions about sudden oak death. Because the pathogen can be transported in soil, sanitation is key to controlling the disease's spread. But people sometimes have taken unnecessarily extreme precautions after hiking in infested areas. "Some threw their shoes away right after hiking," says Alexander, who is based in Marin County. "Others put all their clothes in a paper bag, washed them right away and then burned the bag." But all hikers really need to do is to clean clumps of mud off their shoes during the rainy season, she says.

Another misconception is that people in susceptible coastal areas should avoid gardening with native plants. "Some see the host plant list as a prohibition list," Alexander says. "But aside from bay laurels, they all should be planted. Natives are better than nonnatives, which could introduce another pathogen." Bay laurel trees are the main host responsible for spreading $P$. ramorum in California wildlands.

Most recently, research has shown that sudden oak death infections are not affected by azomite, a mineral-rich powder that is mined from volcanic deposits (see page 10). While azomite is touted as a natural cure, "it's like treating pneumonia with orange juice," says study leader Matteo Garbelotto, a

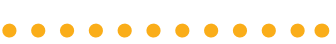

Matteo Garbelotto of UC Berkeley demonstrates sudden oak death diagnosis and treatment for members of the media at the Berkeley campus.
UC Cooperative Extension (UCCE) forest pathology specialist at UC Berkeley.

The only proven sudden oak death treatment is phosphonates, which boost plants' defense systems; this treatment is primarily preventative and is only feasible for individual or small groups of trees. "Azomite appeals emotionally to a lot of people," Alexander says. "Now we'll be able to tell them that it doesn't work." 


\section{"SOD Blitzes" monitor spread}

Recent outreach efforts do double-duty by involving stakeholders in research on $P$. ramorum's spread. Local communities help UCCE's Garbelotto monitor bay laurel trees, which are typically harbingers of infestation, at the edges of areas with sudden oak death. Participants in these weekend events, called "SOD Blitzes," learn how to identify diseased plants and collect bay laurel samples. Then they intensively canvas their areas, which include neighborhoods, open spaces and nature preserves, and give their samples to Garbelotto. After testing the samples for $P$. ramorum, he returns to the communities with maps of the collection points and any infected spots.

First held during spring 2008 with funding from the U.S. Forest Service's State and Private Forestry Office, SOD Blitzes have revealed new infections in the East Bay, the San Francisco Peninsula and Carmel Valley. Pinpointing the pathogen's locations helps communities manage the disease.

"This is a wonderful way to do something when it's really needed rather than blanketing the landscape with a series of treatments that may not be necessary," Garbelotto says. The three newly infested areas will be "SOD Blitzed" again in spring 2009. "Changes in distribution from one year to the next should tell us a lot about the local potential for expansion of this pathogen," he says.

\section{Working with tribes}

Similarly, Hoopa and Yurok tribes participate in a study that tracks sudden oak death throughout coastal Northern California watersheds, which is led by David Rizzo of UC Davis. P. ramorum spores can be carried far ahead of an infection edge in streams. The tribes monitor streams for the pathogen on their lands by using rhododendron leaf baits to attract any swimming $P$. ramorum zoospores. The tribal lands are in uninfested parts of Humboldt County, and so far the monitoring has not revealed new infections.

"We value our research partnership with the tribes," says COMTF's Lee, who is based in Eureka and is also one of the study's researchers. "They do all the baiting themselves. They are cautious over who has access to their land because they don't want it to become infested." Lee has also trained tribes to survey their lands for trees with sudden oak death symptoms.

Tribes are among those most affected by sudden oak death because many of the host plants are integral parts of their culture. "Acorns are an important source of food and bay laurels are im-

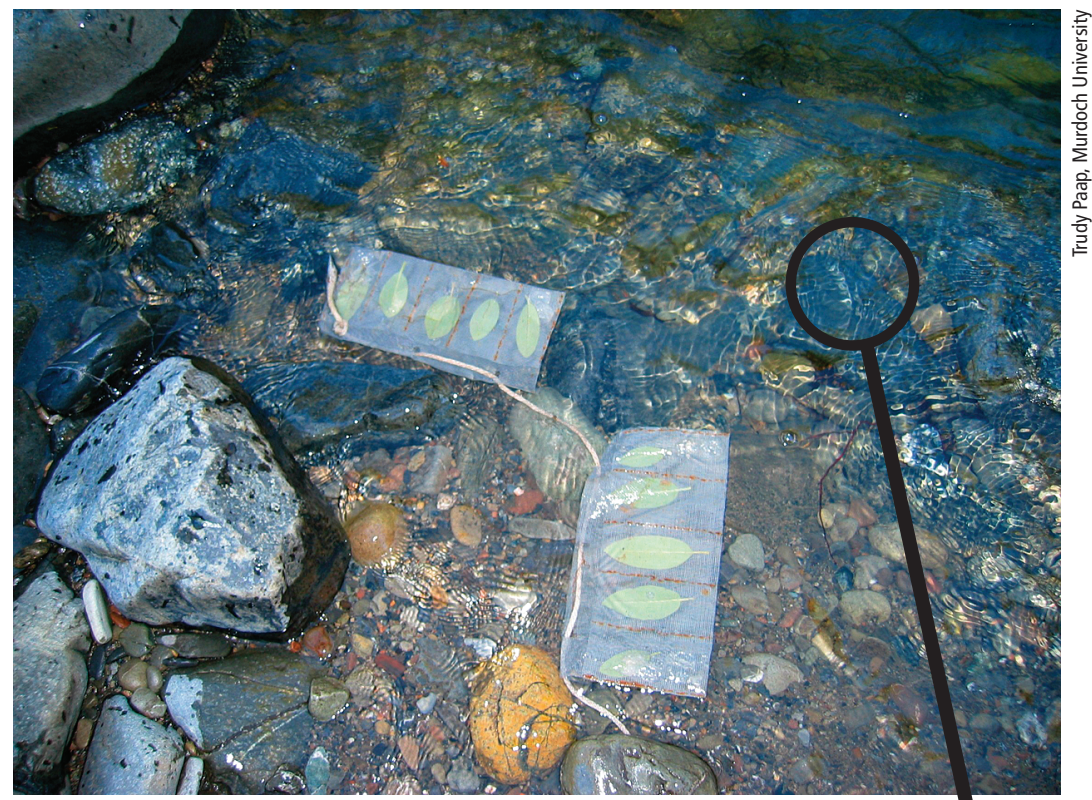

Researchers use a mesh baiting bag filled with rhododendron leaves to "fish for Phytophthora." The bag is retrieved in a few weeks and symptomatic leaves are tested for the pathogen's presence. Below, P. ramorum chlamydospores grow on agar.

portant in ceremonies," Alexander says. To help tribes use plants safely, COMTF launched a Native Plant and Tribal Resources Web page in fall 2008. The page lists native plants associated with sudden oak death, with their traditional names and uses by various tribes, and provides guidelines for plant gatherers. Recommendations specific to tribes include burning any unused plant parts such as stripped bark, and boiling any water that has been used to soak twigs used to make baskets; both measures destroy the pathogen.

\section{Treatment workshops}

To make sudden oak death information even more accessible, Garbelotto recently began offering on-campus treatment workshops. "Many workshops are geared toward professional tree-care specialists," he says. "This lets us share our knowledge with the public in a regular fashion."

Offered monthly during the academic year, these informal 2-hour sessions cover preventative treatments for the disease. Participants learn how to choose trees likely to benefit from treatments, and get to observe field demonstrations of phosphonate treatments.

"We advise treating oaks with no sign of infection when symptoms show up on neighboring bay laurels," Garbelotto says. "We also advise that even if some oaks have died in a grove, it may be possible to protect those that have not been infected." - Robin Meadows
For more information:

California Oak Mortality Task Force http://www.suddenoakdeath.org

Matteo Garbelotto's laboratory http://nature.berkeley.edu/ garbelotto/english/index.php

UCTV 2008 SOD video http://www.youtube.com/ watch? $v=$ jWmg5PVK1I 